\title{
Prenatal Mucopolysaccharidosis II (Hunter): A Pathogenetic Study
}

\author{
ULRICH N. WIESMANN, ${ }^{(29)}$ MAX A. SPYCHER, CLAUS MEIER, INGE LIEBAERS, AND NORBERT \\ HERSCHKOWITZ \\ Department of Pediatrics [U. N.W., N. H.J: Department of Neurology of the University of Berne, Switzerland \\ [C. M.] \\ Department of Histopathology, University of Zurich. Switzerland [M. A. S.]; and Department of Pediatrics, Free \\ University of Brussels, Belgium [I. L.]
}

\begin{abstract}
Summary
A prenatal diagnosis of Mucopolysaccharidosis II (M. Hunter) was made early in a pregnancy at risk in a family with one affected child. An affected fetus was diagnosed on the basis of an abnormal incorporation and degradation of ${ }^{35} \mathrm{SO}_{4}$ in ${ }^{35} \mathrm{SO}_{4}$-labeled mucopolysaccharides in cultured amniotic cells. Dermatan sulfate and heparin sulfate concentrations in the supernatant of the amniotic fluid were high.

In the aborted fetus, the diagnosis could be confirmed by ${ }^{35} \mathrm{SO}_{4}$ incorporation studies in the cultured fibroblasts and in cultured brain cells as well as by the deficiency of the specific enzyme activity (iduronide sulfate sulfatase) in the organs of the fetus. $\beta$ Galactosidase was in the low normal range in liver and spleen but significantly reduced in brain. Under electron microscopy, the mesenchymal cells of liver and spleen showed lysosomal storage of material, presumably mucopolysaccharides, in excess of normal. In the neurons of the spinal ganglia and spinal cord, "Zebra bodies" in statu nascendi were observed.
\end{abstract}

\section{Speculation}

Primary and secondary effects of the deficiency in iduronide sulfate sulfatase in the severe form of mucopolysaccharidosis II can be demonstrated in the affected fetus as early as the 22nd wk of gestation. In the fetal brain, an inhibition of $\beta$-galactosidase by the accumulating mucopolysaccharides leads to a secondary accumulation of gangliosides in ultrastructurally visible lysosomal "Zebra bodies."

Mucopolysaccharidosis II is a sex-linked genetic disturbance of mucopolysaccharides (MPS) metabolism due to a deficiency of iduronide sulfate sulfatase $(1,6,17)$.

The disease exists in a severe form with an early onset of the symptoms, severe mental retardation, and physical handicaps (21) and in a mild form with no mental disability and only moderate skeletal dysplasia (25).

Prenatal diagnosis to prevent the birth of another affected child by abortion is an ultimate measure that may bear psychological and ethical consequence for both parents and doctors. In all cases, the diagnosis must therefore be confirmed, and the fetus should serve to further studies of the pathogenesis of the disorder. The present collaborative study is the result of a prenatal diagnosis in a pregnancy at risk for mucopolysaccharidosis II. It was carried out on the affected fetus in the 22 nd wk of gestation.

\section{PRENATAL HUNTER: CASE HISTORY}

The first child of unrelated healthy parents was delivered after an uneventful pregnancy. Psychomotor development was normal up to the age of $1 \frac{1 / 2}{2}$ years, at which time the clinical diagnosis of M. Hunter was made on the basis of the typical facies, typical skeletal deformities, a pair of inguinal hernias, mental retardation, and excessive excretion of heparin sulfate and dermatan sulfate in the urine.

The diagnosis of $\mathrm{M}$. Hunter was confirmed using cultured fibroblasts of the patient. Incorporation of ${ }^{35} \mathrm{SO}_{4}$ into sulfated MPS was abnormal, and the rate of disappearance of the ${ }^{335} \mathrm{SO}_{4}$ from the ${ }^{35} \mathrm{SO}_{4}$-labeled MPS was very much retarded. In crosscorrection experiments, mixed cultures of the patients fibroblasts corrected the ${ }^{35} \mathrm{SO}_{4}$-labeled MPS degradation of Hurler, but not of known Hunter fibroblasts, thus indicating identity with Hunter cells (7).

The second pregnancy was monitored by amniocentesis in the 14th wk of gestation. The culture of the amniotic cells revealed an affected male fetus on the basis of an abnormal ${ }^{35} \mathrm{SO}_{4}$-labeled MPS metabolism. In the supernatant of the centrifuged amniotic fluid, an increased concentration of MPS with an abnormally high proportion of hyaluronidase-resistant heparin sulfate and dermatan sulfate gave additional evidence for an affected fetus.

An abortion was performed at 22 wk of gestation by hysterotomy. At autopsy, material for fibroblast and dissociated primary brain cell culture as well as for electron microscopy was obtained. Unfixed specimens of the organs were frozen at $-80 \mathrm{C}$ for enzyme determination. A normal fetus aborted at 22 wk of gestation because of a social indication was obtained for biochemical tissue culture and ultrastructural studies.

Amniocentesis during a third pregnancy two years later revealed monozygous female twins by chromosomal analysis of the cultured cells. Normal female twins were born at term without complications. The children are now 1 year old and clinically and biochemically normal. All investigations on the patients, the fetuses, and on the cultured cells were performed with the informed consent of the parents.

Table 1. Accumulation and degradation of ${ }^{35} \mathrm{SO}_{4}$-labeled MPS in cultured amniotic cells

\begin{tabular}{lccc}
\hline & $\begin{array}{c}\text { Accumulation' } \\
(\mathrm{dpm} / \mathrm{mg})\end{array}$ & Degradation $^{2}$ & $\%$ \\
\hline $\begin{array}{l}\text { Fetus } \\
\text { at risk }\end{array}$ & 34,300 & 23,900 & 30 \\
$\begin{array}{l}\text { Control } \\
\text { fetus }\end{array}$ & 4,100 & 950 & 77 \\
\hline 1:35 & & & \\
\hline
\end{tabular}

${ }^{1}{ }^{35} \mathrm{SO}_{4}$-Labeled MPS accumulation per $\mathrm{mg}$ cell protein during $48 \mathrm{hr}$ incubation $(=100 \%)$.

${ }^{2}$ In identical treated cultures, the radioactive medium was discarded, the cells were washed in situ with $10 \mathrm{ml}$ of unlabeled medium, and then 10 $\mathrm{ml}$ of unlabeled medium was added during an additional $24 \mathrm{hr}$. Residual ${ }^{35} \mathrm{SO}_{4}$-labeled MPS was measured, and the percentage of disappearance of radioactivity was calculated. The disappearance of radioactivity means degradation and secretion of macromolecular material. 


\section{MATERIALS AND METHODS}

Amnion cell culture (26) and skin fibroblast cultures from the patient and from the aborted fetus as well from biopsies from normal children were performed as previously described (24). For electron microscopy, amnion cells were grown on reconstituted rat tail, collagen-coated Petri dishes. Dissociated primary brain cell cultures from fetal cerebellum were obtained by mincing the tissue with a razor blade in Dulbecco's modified minimal essential medium followed by trituration with a $10 \mathrm{ml}$ Falcon plastic pipet essentially as described previously (27), except that trypsin treatment was omitted, and $10^{7}$ dissociated cells were explanted onto uncoated $75 \mathrm{~cm}^{2}$ Petri dishes containing $10 \mathrm{ml}$ of medium.

Arylsulfatase $A$ and $B$ activities were determined according to Baum et al. (2), $\beta$-galactosidase, $\alpha$-mannosidase, $\beta$-glucuronidase, and $\beta$-glucosidase were determined according to Van Hoof and Hers (23) using 4-methylumbellipheryl derivatives as substrates. Iduronide sulfate sulfatase was determined according to Liebaers et al. (17).

For the study of the ${ }^{35} \mathrm{SO}_{4}$-labeled MPS metabolism in cultured amnion cells, skin fibroblasts, and dissociated primary brain cell cultures, cultures were labeled with $50 \mu \mathrm{Ci}$ carrier-free ${ }^{35} \mathrm{SO}_{4}$ in 10 $\mathrm{ml}$ of medium for $48 \mathrm{hr}$. Intracellular accumulation of ${ }^{35} \mathrm{SO}_{4^{-}}$ labeled MPS was determined according to Fratantoni et al. (7). Degradation of ${ }^{35} \mathrm{SO}_{4}$-labeled MPS was measured as the rate of disappearance of ${ }^{35} \mathrm{SO}_{4}$ label from $48 \mathrm{hr}$ prelabeled cells during a 24 - $\mathrm{hr}$ chase. In the brain cell cultures ${ }^{35} \mathrm{SO}_{4}$-labeled sulfatide was extracted from the cells by the Folch procedure as described previously (13).

For electron microscopical observations, fresh specimens from liver, kidney, spleen, peripheral nerve, spinal ganglion, spinal cord, cerebrum, and cerebellum were cut to $1 \mathrm{~mm}^{3}$ pieces with the help of a razor blade. They were fixed in $4 \%$ buffered glutaraldehyde (liver, spleen, and kidney) and/or 1\% phosphate-buffered Os $\mathrm{O}_{4}$ (brain). After washing with buffer, the material was dehydrated in acetone and then embedded in Epoxy resin (araldite). Thin sections were stained with uranyl acetate and viewed in a Philips EM 300 microscope.

\section{RESULTS}

\section{PRENATAL DIAGNOSIS}

Uronic acid content in the supernatant of the amniotic fluid was $24.8 \mu \mathrm{g} / \mathrm{ml}$, equivalent to $75 \mu \mathrm{g} / \mathrm{ml}$ of glycosamino-glycans.

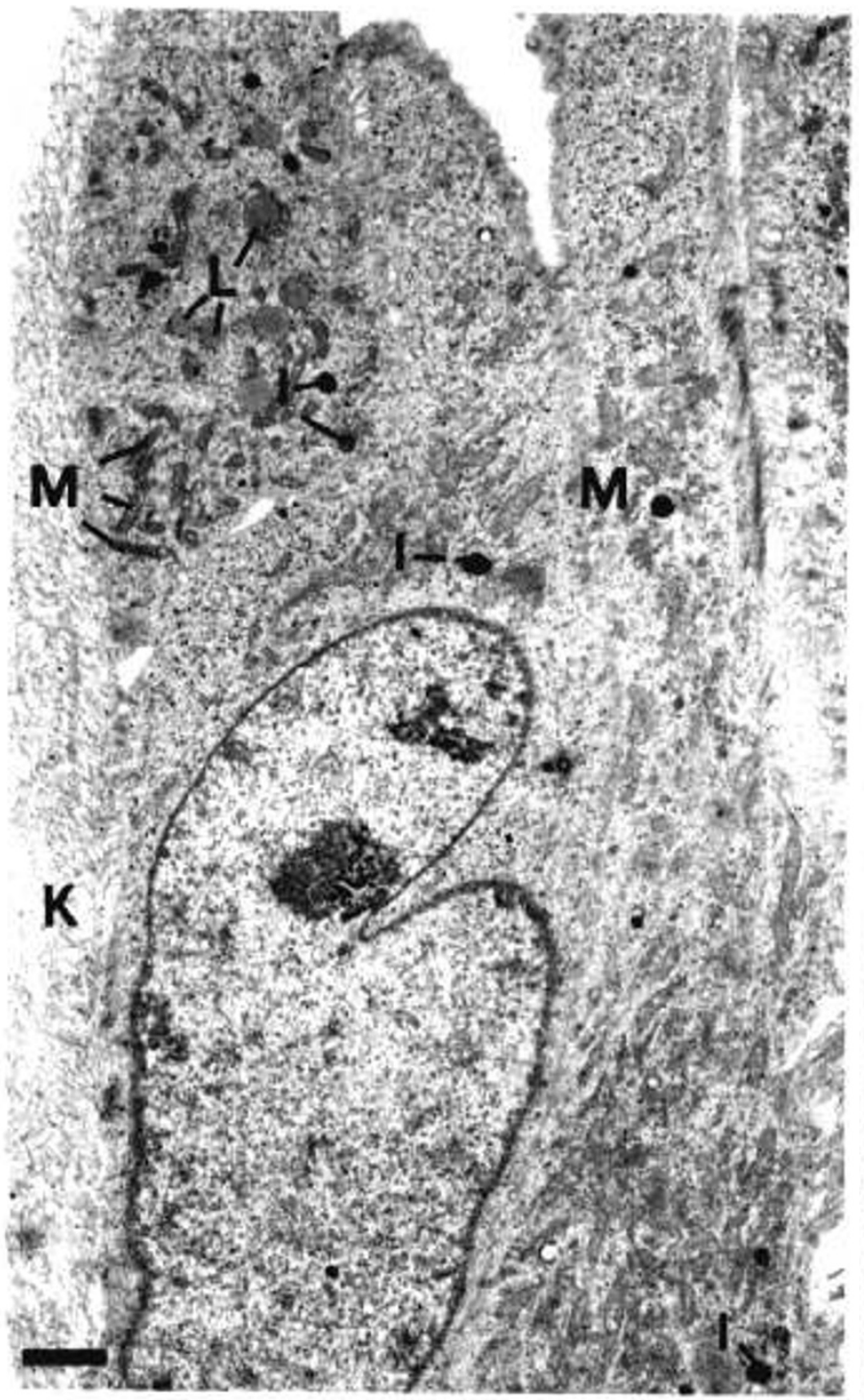

$1 \mathrm{a}$

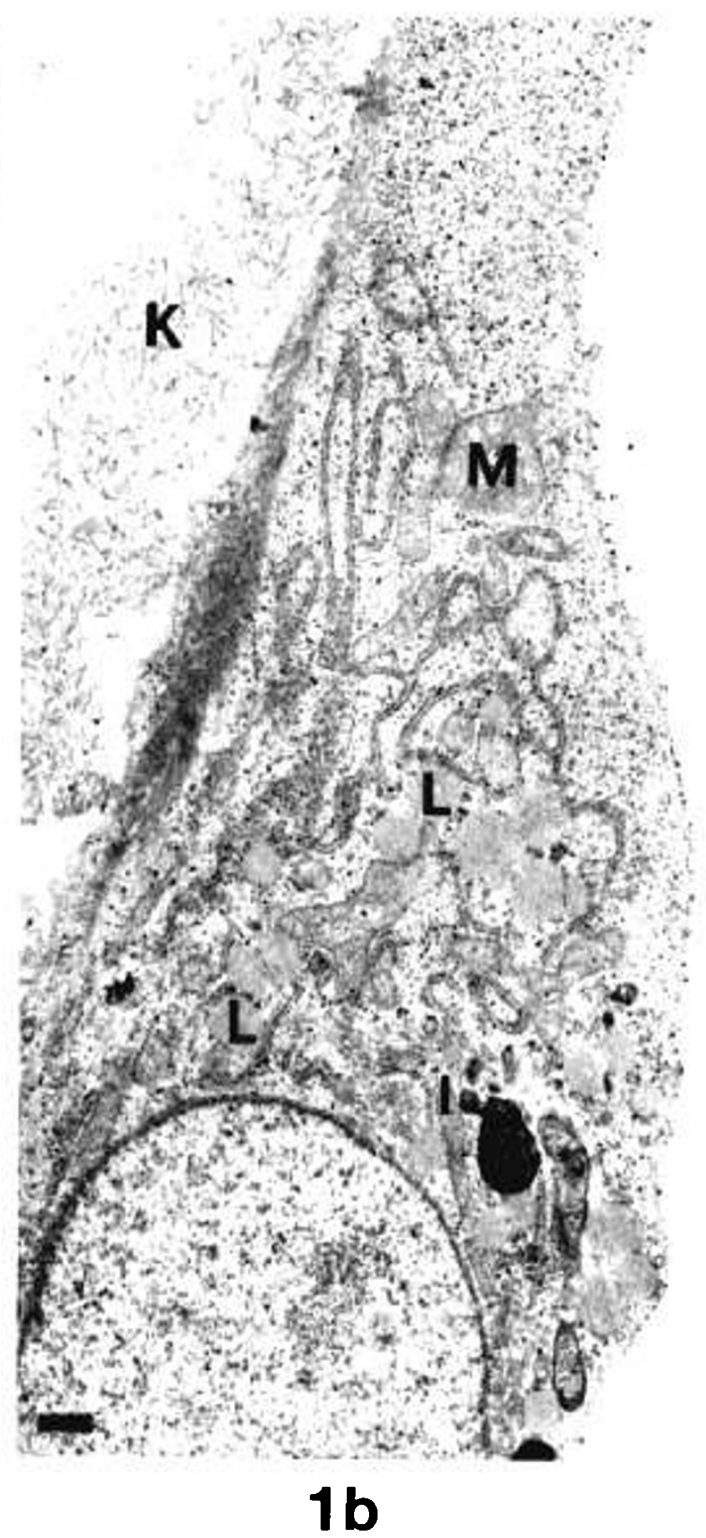

Fig. 1. Cultured amniotic cells. The cytoplasm has a normal appearance; no storage vacuoles can be seen. The numerous small lipid inclusions ( $L$ ) are a normal feature of cultured cells. ( $M$, mitochondira; $K$, collagen-supporting layer; $\square$, lysosomes). $a, \times 5300$ patient; $b, \times 8400$ normal. 
The hyaluronidase-resistant material (dermatan and heparin sulfates) was clearly elevated $(85 \%)$ versus chondroitin sulfate and hyaluronic acid which was $15 \%$. These results were obtained by courtesy of Dr. Michael Dean, Mathilda and Terence Kennedy, Institute of Rheumatology, London, W6 7DW, Great Britain.

The accumulation and disappearance of ${ }^{35} \mathrm{SO}_{4}$-labeled MPS in the cultured amniotic cells is shown in Table 1. One wk after subculture, the cells from the fetus at risk accumulated eight times more ${ }^{35} \mathrm{SO}_{4}$-labeled MPS during $48 \mathrm{hr}$ than did the normal control cells and lost during $24 \mathrm{hr} 30 \%$ instead of $77 \%$ (normal control) of the amount of ${ }^{35} \mathrm{SO}_{4}$-labeled MPS previously accumulated.

Electron microscopy of the cultured amniotic cells was performed 1 wk after subculture of the cells on collagen-coated, 100$\mathrm{mm}$ Falcon plastic Petri dishes (Fig. 1). No significant difference in the lysosomal morphology was observed between the cells of the fetus at risk and normal cells. At 3 wk after subculture, activities of lysosomal enzymes in the cultured amniotic cells of the fetus at risk were the same as in the matching control cells (Table 2) except for $\beta$-galactosidase which was reduced to $20 \%$ of normal.

\section{ENZYMATIC ANALYSES OF THE FETUS AT RISK}

The activities of the iduronide sulfate sulfatase in the organs of the fetus at risk are summarized in Table 3 . All values of the fetus, especially those for the brain, are significantly lower than in the age-matched control organs.

Activities of other lysosomal enzymes in the fetal organs are shown in Table 4. They were all within the limits of the values for the control fetuses except for the activity of $\beta$-galactosidase in the brain, which is significantly reduced to about $30 \%$ of normal.

Table 2. Lysosomal enzymes in cultured amniotic fibroblasts (3 wk after subculture)

\begin{tabular}{lcc}
\hline & $\begin{array}{c}\text { Control } \\
\text { cells } \\
(\mu \text { moles } / \min / g \\
\text { protein })\end{array}$ & $\begin{array}{c}\text { Fetus at } \\
\text { risk } \\
(\mu \text { moles } / \mathrm{min} / \mathrm{g} \\
\text { protein) }\end{array}$ \\
\hline$\beta$-Galactosidase & 2.4 & 0.5 \\
$\begin{array}{l}N \text {-Acetyl- } \beta \text {-Galactosaminidase } \\
\text { (total) }\end{array}$ & 3.2 & 4.4 \\
Arylsulfatase A & 0.21 & 0.19 \\
\hline
\end{tabular}

Table 3. Activity of iduronide sulfate sulfatase in fetal organs ${ }^{1}$

\begin{tabular}{lccc}
\hline \multicolumn{1}{c}{ Tissues } & Patient & Control & $\% N$ \\
\hline Cerebrum & 2.1 & 495 & 0.42 \\
Cerebellum & 7.5 & & \\
Liver & 20 & 2552 & 0.8 \\
Kidney & 17 & 874 & 1.9 \\
\hline
\end{tabular}

1 The activity of the enzyme was calculated as follows. The substrate in $\mu$ moles present in the incubation solution was multiplied by the percentage of product formed and expressed as $\mu$ moles of product formed per $24 \mathrm{hr}$ and per $\mathrm{g}$ of frozen tissue.
Accumulation and disappearance of ${ }^{35} \mathrm{SO}_{4}$-labeled MPS in $\mathrm{fi}$ broblasts cultured from the fetal skin was greatly abnormal as presented in Table 5. In cultured dissociated cells from the fetal cerebellum, the accumulation of ${ }^{35} \mathrm{SO}_{4}$-labeled MPS was $1^{3 / 4}$ times that of an age-matched normal control brain culture. The percentage of degradation in the affected fetus was 50 versus $85 \%$ in the control cultures (Table 6). In order to prove that the cultures contained brain-specific cells, ${ }^{35} \mathrm{SO}_{4}$ incorporation into ${ }^{35} \mathrm{SO}_{4}$-labeled sulfatide was also investigated. Accumulation of ${ }^{35} \mathrm{SO}_{4}$ in the sulfatide and degradation of ${ }^{35} \mathrm{SO}_{4}$ sulfatide was similar in the brain cultures of the affected and of the control fetus.

\section{ULTRASTRUCTURAL MORPHOLOGY IN FETAL ORGANS}

\section{LIVER}

In most hepatocytes, storage of a floccular material of moderate electron density could be demonstrated (Fig. $2 a$ ). The storage

Table 5. Accumulation and degradation of ${ }^{35} \mathrm{SO}_{4}$-labeled MPS in cultured fetal skin fibroblasts

\begin{tabular}{|c|c|c|c|}
\hline & $\begin{array}{l}\text { Accumu- } \\
\text { lation' } \\
\text { (dpm } / \mathrm{mg} \\
\text { protein) }\end{array}$ & $\begin{array}{l}\text { Degra- } \\
\text { dation }{ }^{2} \\
\text { (dpm/mg } \\
\text { protein) }\end{array}$ & $\%$ degradation \\
\hline $\begin{array}{l}\text { Fetus affected } \\
\text { with MPS-osis }\end{array}$ & 55,200 & 44,700 & 14 \\
\hline Control fetus & 17,100 & 1,550 & 90 \\
\hline
\end{tabular}

${ }^{135} \mathrm{SO}_{4}$-Labeled MPS accumulation per $\mathrm{mg}$ cell protein during $48 \mathrm{hr}$ incubation $(=100 \%)$.

${ }^{2}$ In identically treated cultures, the radioactive medium was discarded, the cells were washed in situ with $10 \mathrm{ml}$ of unlabeled medium, and then 10 $\mathrm{ml}$ of unlabeled medium was added during an additional $24 \mathrm{hr}$. Residual ${ }^{35} \mathrm{SO}_{4}$-labeled MPS was measured, and the percentage of disappearance of radioactivity was calculated.

Table 6. Metabolism of ${ }^{35} \mathrm{SO}_{4}$-labeled compounds in dissociated fetal cerebellar brain cell cultures Accumulation' (dpm/mg Degradation ${ }^{2}(\mathrm{dpm} / \mathrm{mg}$ protein) protein)

\begin{tabular}{|c|c|c|c|c|}
\hline & Control & Patient & Control & Patient \\
\hline $\begin{array}{l}{ }^{35} \mathrm{SO}_{4} \text {-Labeled } \\
\text { MPS }\end{array}$ & 160,000 & 280,000 & $\begin{array}{c}25,000 \\
(85.5 \%)^{3}\end{array}$ & $\begin{array}{r}140,000 \\
(50 \%)\end{array}$ \\
\hline $\begin{array}{l}{ }^{35} \mathrm{SO}_{4} \text {-Labeled } \\
\text { sulfatide }\end{array}$ & 6,200 & 6,800 & $\begin{array}{r}3,000 \\
(51.5 \%) \\
\end{array}$ & $\begin{array}{r}2,500 \\
(63.2 \%) \\
\end{array}$ \\
\hline
\end{tabular}

${ }_{135} \mathrm{SO}_{4}$ incorporation into ${ }^{35} \mathrm{SO}_{4}$-labeled MPS and into ${ }^{35} \mathrm{SO}_{4}$-labeled sulfatide during a $48-\mathrm{hr}$ incubation $(=100 \%)$.

${ }^{2} \mathrm{Residual}$ radioactivity of ${ }^{35} \mathrm{SO}_{4}$-labeled MPS and sulfatide after a $24-$ $\mathrm{hr}$ incubation with unlabeled medium.

${ }^{3}$ Numbers in parentheses, values expressed as a percentage of ${ }^{35} \mathrm{SO}_{4}$ labeled MPS and ${ }^{35} \mathrm{SO}_{4}$-labeled sulfatide disappearing from the cells per $24 \mathrm{hr}$.

Table 4. Lysosomal enzymes in fetal organs

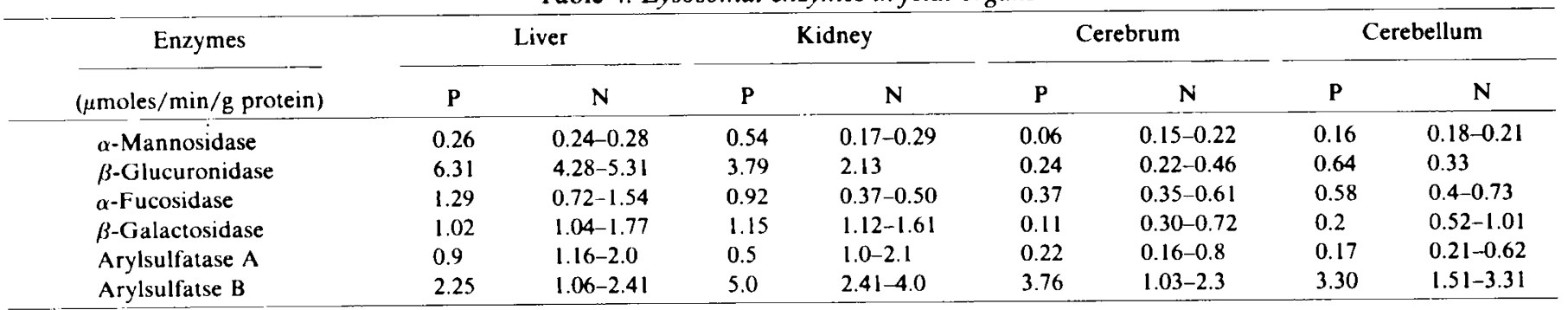

' $P$, patient; $N$, normal fetuses 16 to 23 wk of gestation $(N=4)$, range of values. 
material is embedded in small vacuoles measuring up to $3 \mu \mathrm{m}$ and formed by a tripartite delimiting membrane (Fig. $2 b$ ). Some vacuoles also comprise a strongly osmiophilic component in addition to the floccular masses (Fig. 2c). Large storage vacuoles could also be observed in the cells close to the portal blood vessels (presumptive bile duct epithelial cells) (Fig. 3). In addition, aggregates of morphologically identical storage vacuoles were observed in the sinusoidal lining cells as well as in the endothelial cells of the portal veins and arteries (Fig. 4).

\section{NERVOUS SYSTEM}

The storage of a granular electron-lucent material in vacuoles of 0.5 to $1 \mu \mathrm{m}$ diameter could be demonstrated in peripheral nerves, spinal ganglia, spinal cord, cerebellum, cerebrum, and the meninges. The storage process was most advanced in mesenchymal cells of the meninges (Fig. 5), but endoneurial fibroblasts of the peripheral nerves also contained many vacuolar inclusions. Finely granular storage material was also found in the endothelial cells of capillaries in peripheral nerves, spinal ganglia, spinal cord, cerebellum, and cerebral cortex. In the central nervous system, the storage process was related to the degree of differentiation. In neurons and neuroblasts of the poorly developed cerebral and cerebellar cortex, only few vacuoles filled with a granular material can be demonstrated, whereas the well-developed neurons in the spinal cord exhibited many polymorphous inclusion bodies (Fig. 6). Three types could be differentiated: (1) vacuoles filled with a granular electron-translucent material identical to those described

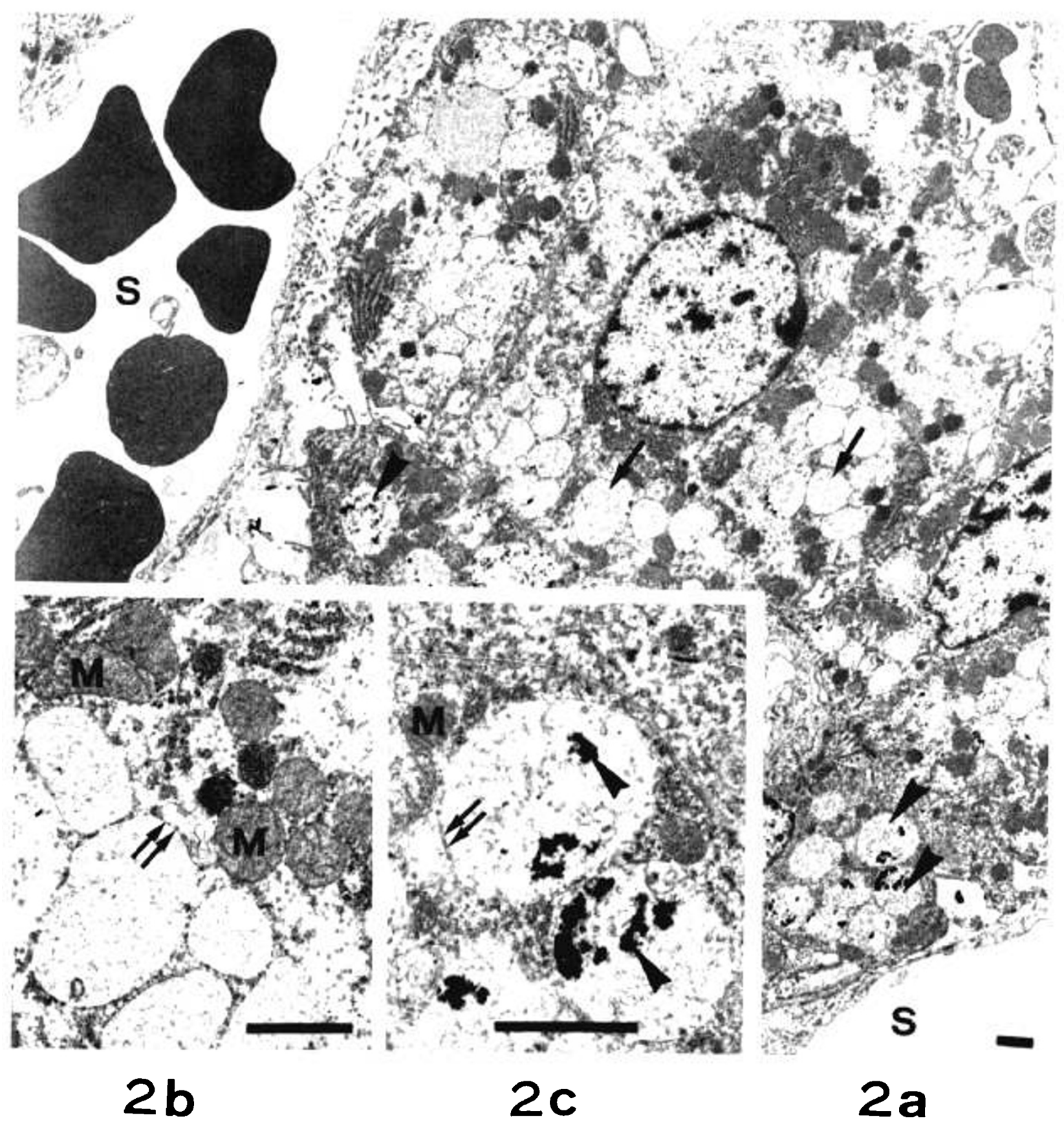

Fig. 2. $a$, hepatocyte showing numerous storage vacuoles containing floccular material of moderate density (arrows). Sometimes the vacuoles also contain inclusions of high electron density (arrowheads). $S$, sinusoidal lumen. $\times 5300 ; b$ and $c$, high-power micrograph of hepatocellular storage vacuoles. The storage material, mainly floccular in appearance, may contain amorphous and strongly osimophilic masses (arrowheads). Due to autolytic processes or to fixation artefacts, the surrounding vacuolar membrane (double arrows) is often interrupted. M. mitochondria. $b, \times 15700 ; c, \times 21800$ 


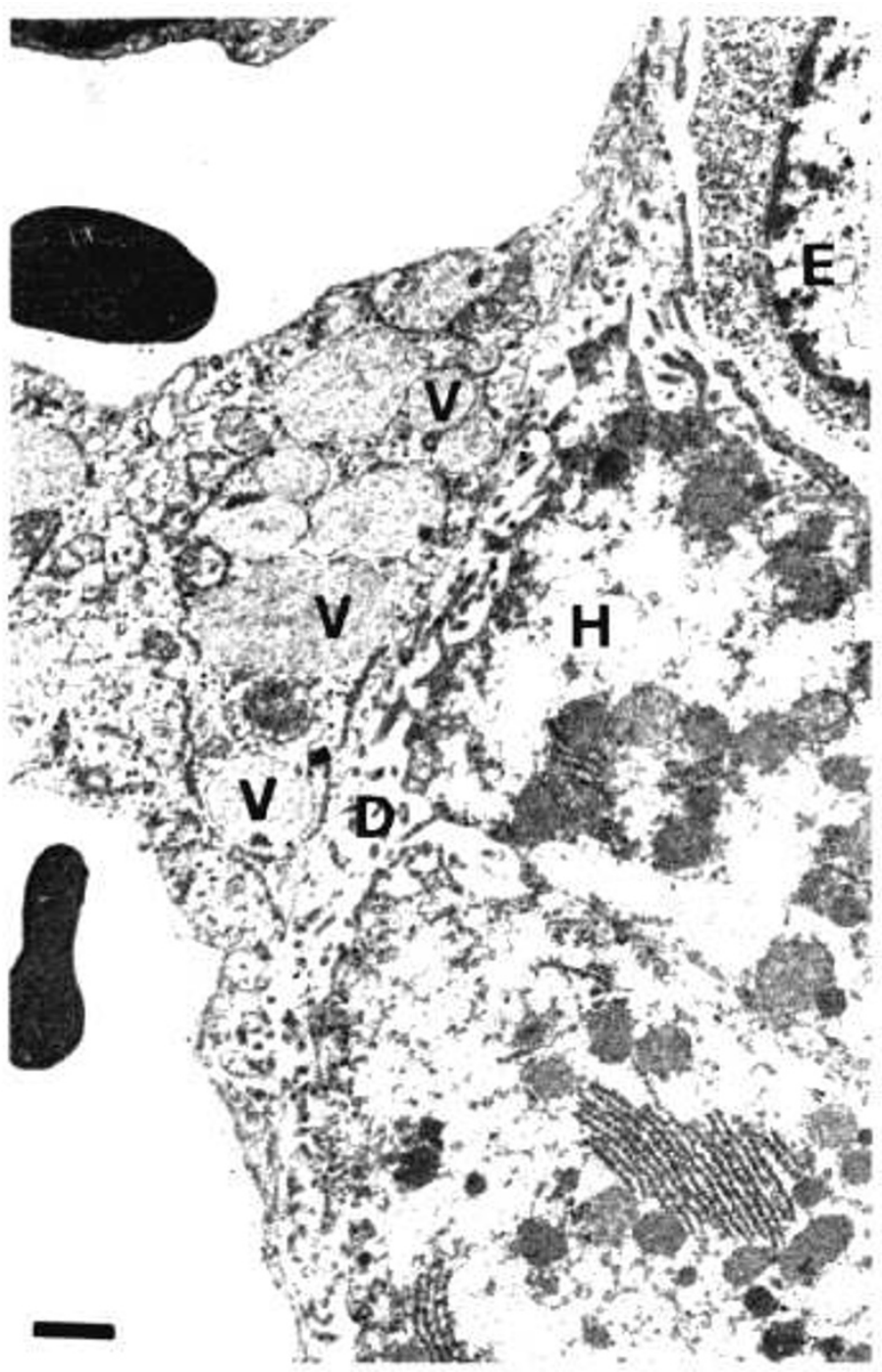

Fig. 3. Sinusoidal lining cell (Kupfer cell) showing numerous storage vacuoles $(V) . D$, Dissé space; $E$, erythroblast: $H=$ hepatocytes. $\times 7900$.

above; (2) "Zebra bodies" with a lamellar pattern of alternating dark and light lines with a periodicity of about $55 \AA$; (3) a vacuolar body with a light granular matrix as in type 1, exhibiting only slight condensations of a lamellated material. From its appearance, this type of inclusion seemed to be an intermediate form between the clear vacuoles and the Zebra-bodies (Fig. 7). Few astrocytes contained inclusions of the vacuolar type, but never Zebra-bodies. Myelination in peripheral nerves and the central nervous system showed no significant difference as compared to a normal fetus of the same age (19).

\section{DISCUSSION}

Prenatal diagnosis of mucopolysaccharidosis II during early pregnancy is sometimes performed in families with an affected child. In some cases, help is sought by pregnant women whose maternal uncle was affected by the disease. Identification of possible carriers has been attempted by analysis of the reduced activity of iduronide sulfate sulfatase in isolated white blood cells (17) but has failed to fully exclude false negative females. Therefore, prenatal diagnosis remains the only way to prevent the birth of another child with the disorder. In all cases where the diagnosis of a type II mucopolysaccharidosis is firmly established in a previous patient, prenatal mucopolysaccharidosis II can be diagnosed in cultured amniotic cells by the excessive accumulation of ${ }^{35} \mathrm{SO}_{4}$-labeled MPS (8) and by the determination of the specific enzyme deficiency of iduronosulfate sulfatase in the amniotic fluid (16) or in the cultured cells. The direct measurement of the iduronosulfate sulfatase activity will eventually replace the ${ }^{35} \mathrm{SO}_{4}$ incorporation test when the substrates for the determination of that enzyme become commercially available for laboratories doing prenatal diagnosis. Because the results of the biological test may range to some extent with the duration of the amnion culture after the last subculture, standardized tissue culture conditions are compulsory.

Unfortunately, no morphologic criteria of lysosomal storage in cultured amnion cells could be found which would have been a time-saving alternative to the biological test which usually takes 3 wk to cultivate enough cells. Despite the fact that accumulation of MPS in amnion cells could not be observed morphologically, the accumulation may have been important enough to inhibit the activity of $\beta$-galactosidase to $20 \%$ of the control.

Abortion of an affected fetus with mucopolysaccharidosis II provides an opportunity to study some aspects of the natural history of the disease and to reveal some insights into the pathogenesis. In the case described, the diagnosis was confirmed in fetal skin fibroblast cultures by determination of the missing enzyme. iduronosulfate sulfatase, and other lysosomal enzymes in the fetal organs and by the electronmicroscopic demonstration of abnormal storage of MPS in lysosomes.

The defective degradation of ${ }^{35} \mathrm{SO}_{4}$-labeled MPS could also be shown in dissociated brain cell culture from the cerebellum of the affected fetus, whereas the synthesis and degradation of the brainspecific ${ }^{35} \mathrm{SO}_{4}$-labeled sulfatide was normal. The morphology of the affected and the normal culture under phase microscopy showed a predominance of astrocytic elements and 10 to $20 \%$

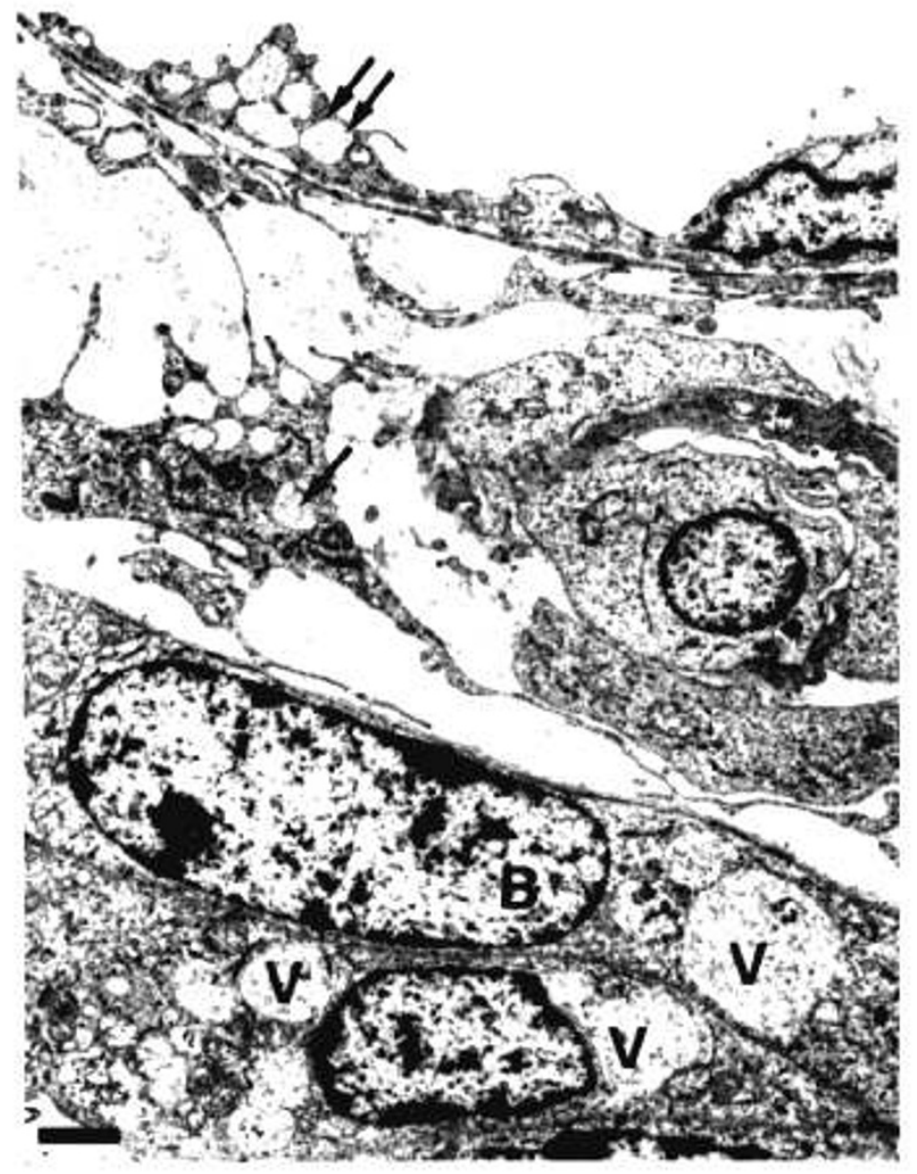

Fig. 4. Low-power micrograph of a portal area. The presumptive biliary epithelia $(B)$ contain storage vacuoles $(V)$. Morphologically similar but smaller vacuoles are also seen in fibroblast cells (arrow) and in endothelial cells of the blood vessels (double arrow). $\times 5900$. 


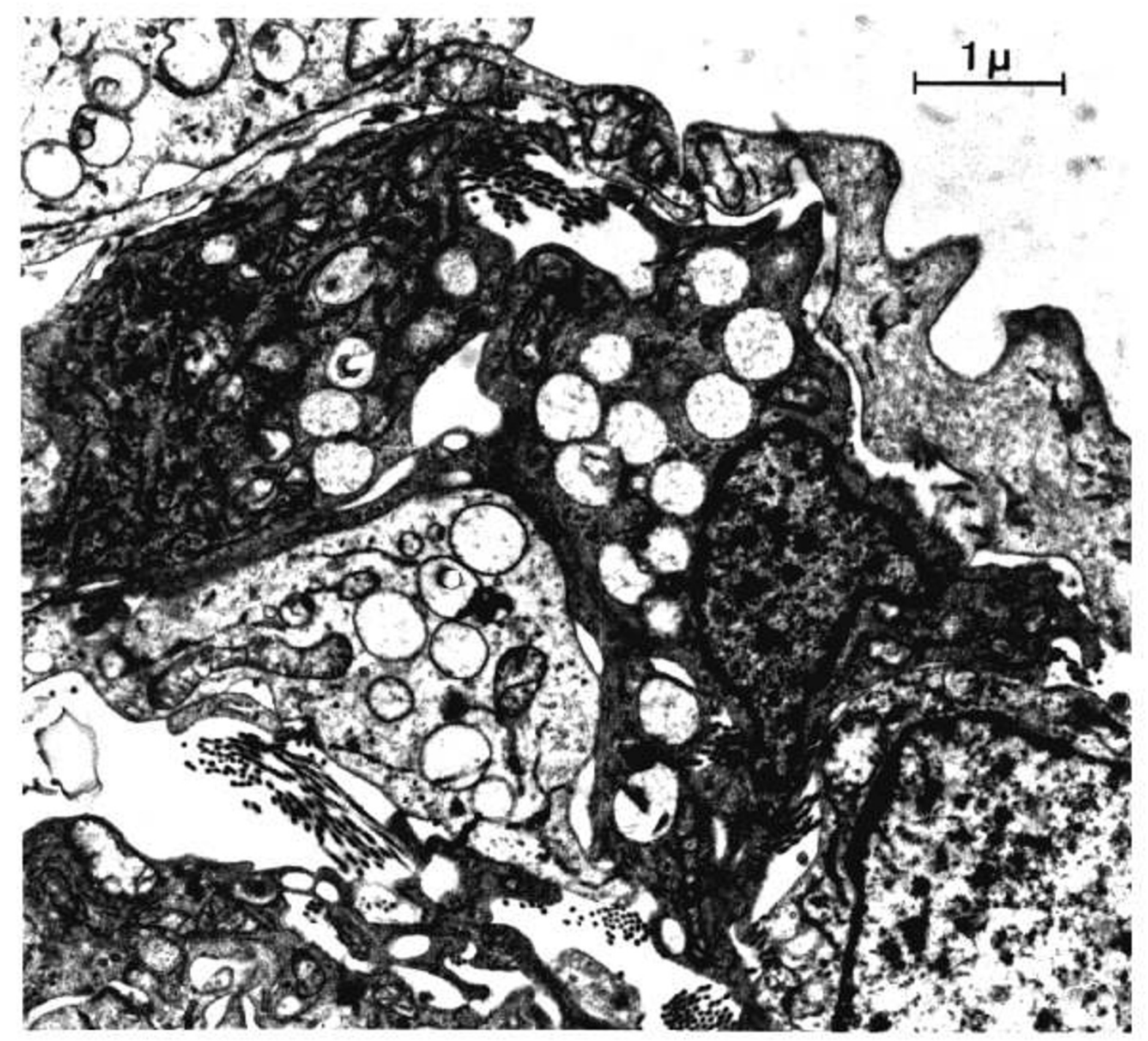

Fig. 5. Meningeal cell containing many vacuoles filled with an electrontranslucent granular material. $\times 13500$. 


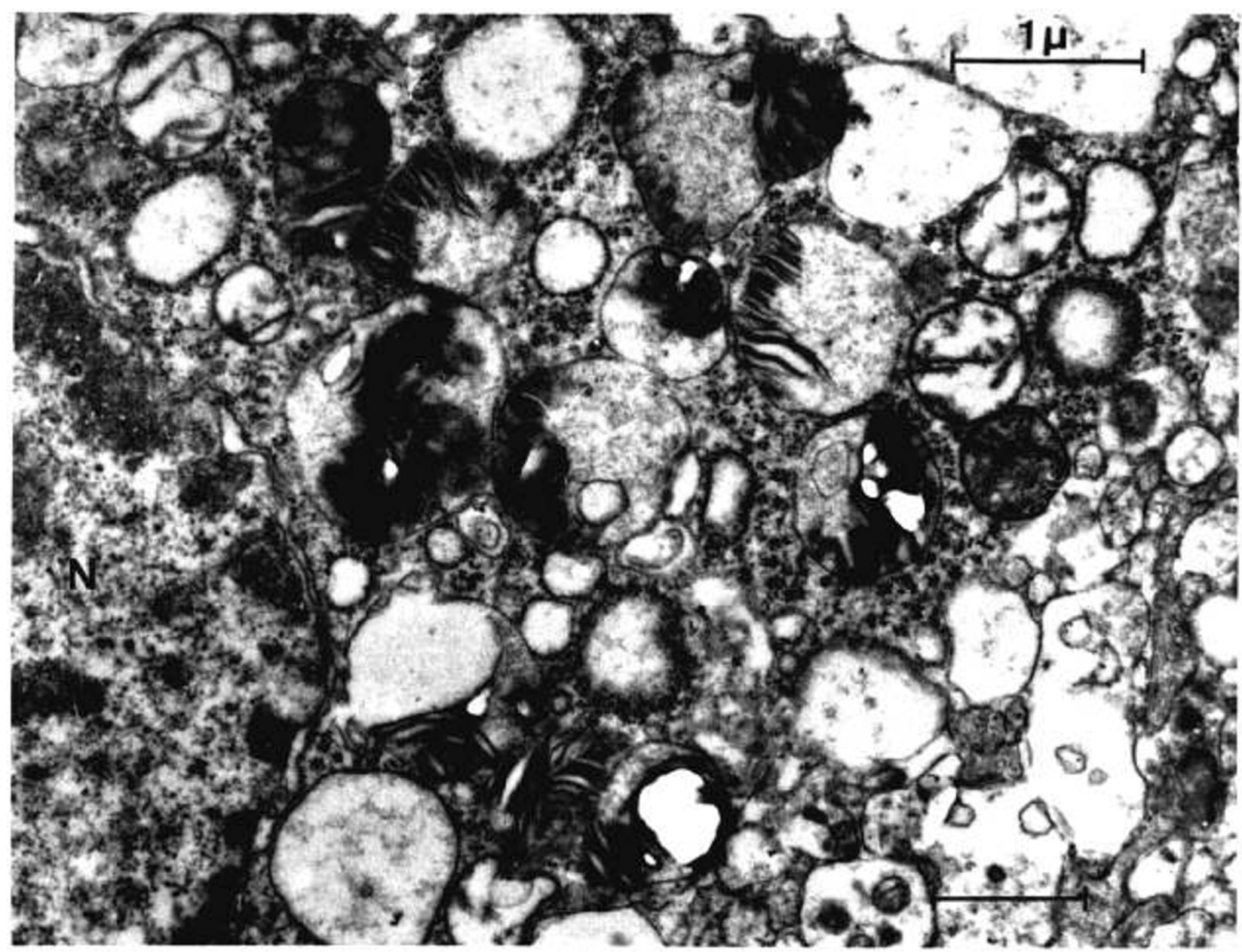

Fig. 6. Spinal motor neuron containing many polymorphous inclusion bodies most of which show a granular matrix and marginal condensations of an osmiophilic material with a lamellar structure. $\times 25000$.
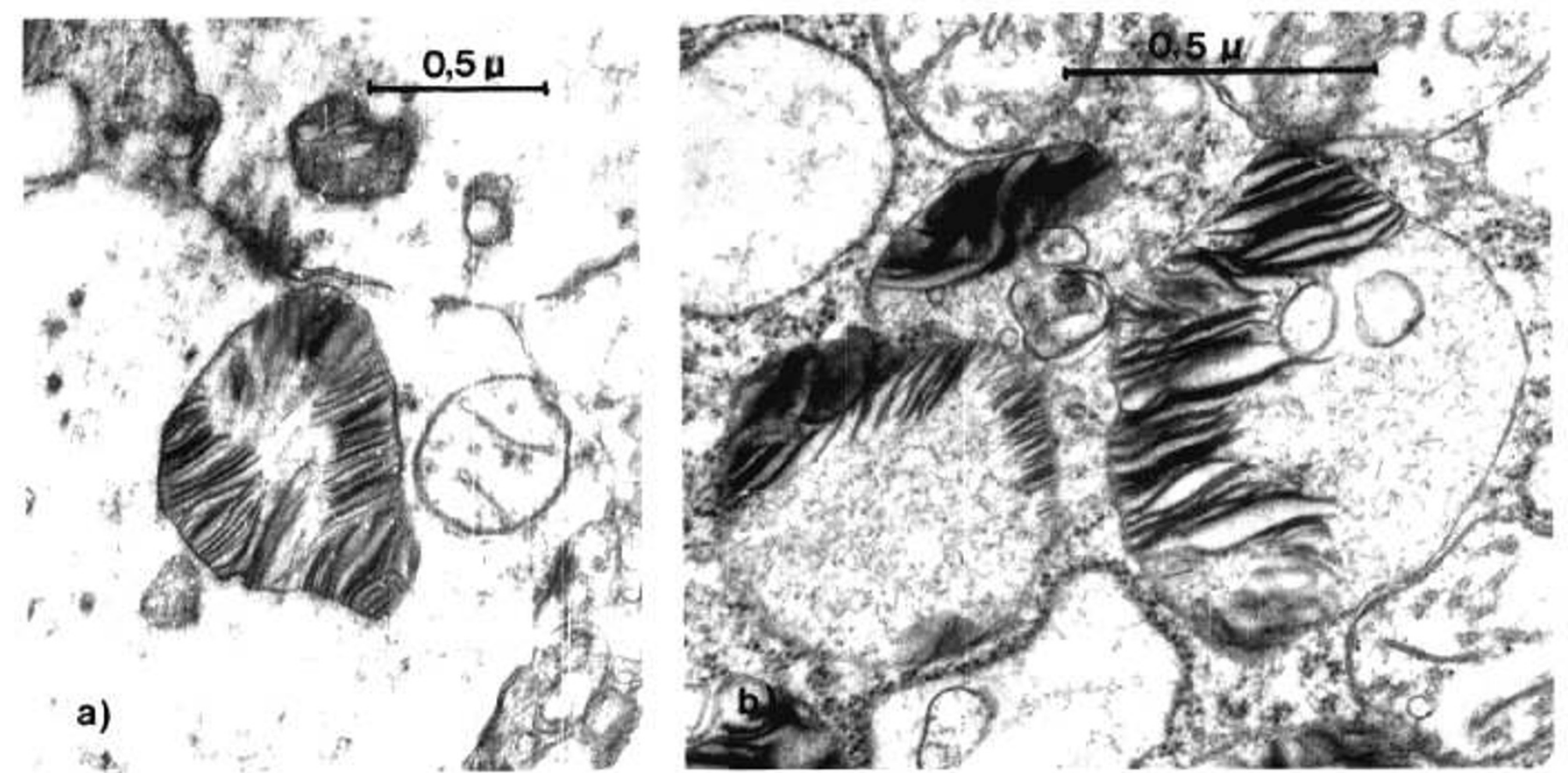

Fig. 7. Neuronal inclusion bodies. $a$, Zebra body in postsynaptic profile; $b$, Zebra bodies in statu nascendi in neuronal pericarion. $\times 18000$ 
putative oligodendroblasts and neurons. Our findings suggest that the brain not only demonstrates the enzyme deficiency, but also demonstrates a functional defect in the metabolism of brainspecific MPS. This evidence is also supported by the morphologic demonstration of MPS storage in the uncultured brain of the fetus.

In all organs analyzed, the activities of lysosomal enzymes other than iduronosulfate sulfatase were normal with the exception of $\beta$-galactosidase activity in the cerebellum and the cerebrum. Dermatan sulfate which accumulates in the tissues of Hunter patients $(4,5)$ was shown to form complexes in vitro with $\beta$-galactosidase (14) and to inhibit its activity $(15,21)$. The inhibition of the enzyme is most expressed towards GM-1 ganglioside degradation (20). In vivo, an inhibition of $\beta$-galactosidase in the tissues of the patients with mucopolysaccharidosis has been repeatedly demonstrated $(9,18)$. The inactivation of $\beta$-galactosidase leads to the secondary storage of galactose-containing lipids, mainly gangliosides, in the lysosomes of the brain cells, morphologically visible as Zebra-bodies. Mental retardation was reported to be correlated with neuronal ganglioside accumulation $(12,22,28)$.

In the patient reported in our study, mental retardation became evident at the end of the first year of life. In this respect, it appears to be important that $\beta$-galactosidase was already low in the brain of the 22-wk-old fetus and that at this time mixed Zebra-bodies were observed containing both lipids and MPS. This suggests that already at this early stage of the developing brain the accumulation of MPS may lead to the inhibition of $\beta$-galactose-containing osmiophilic lipids. In a prenatal Sanfilippo A patient, no such lipid storage but also no storage of MPS in neurons at the third trimester of gestation was found $(10,11)$, although in a 10-yearold patient at autopsy lipid storage was evident in the neuronal cells (3).

Accordingly, mental retardation in Sanfillipo's disease is usually absent during preschool age.

Another possible pathogenetic mechanism in mucopolysaccharidosis is the storage of MPS in mesenchymal cells of the blood vessels and the generalized presence of characteristic lesions around cerebral veins and arteries as shown by Dekaban and Constantopoulos (5) that might impair the blood supply to the patients' brain and thus contribute to the clinical manifestation of the disease. Because storage material also was found in endothelial cells of the capillaries in the brain of the fetus, the cerebrovascular changes in this disease may already start early in life and may partially explain the early onset of the mental retardation.

\section{REFERENCES AND NOTES}

I. Bach. G., Eisenberg. F., Jr., Cantz, M., and Neufeld, E. F.: The defect in Hunter syndrome: deficiency of sulfoiduronate sulfatase. Proc. Natl. Acad. Sci. U. S A., 70: 2134 (1973).

2. Baum, H., Dodgeson, K., and Spencer, B.: The assay of arylsulfatase A and B in human urine. Clin. Chim. Acta, 4: 453 (1959).

3. Cain, H., Egner, E., and Kresse, H.: Mucopolysaccharidosis III A (Sanfilippo disease type A). Histochemical, electronmicroscopical and biochemical findings. Beitr. Pathol. Anat. Allg. Pathol., 160: 58 (1977).

4. Constantopoulos, G. McComb, R. D., and Dekaban, A. S.: Neurochemistry of the mucopolysaccharidoses. Brain glycosaminoglycans, in normal and four types of mucopolysaccharidoses. J. Neurochem.. 26: 901 (1976).
5. Dekaban. A. S., and Constantopoulos. G.: Mucopolysaccharidosis I, II, III and V: pathological and biochemical abnormalities in the neural and mesenchymal elements of the brain. Acta Neuropathol., 39: 1 ( 1977 ).

6. Dorfman. A.. and Matalon. R.: The mucopolysaccharidoses (a review). Proc. Natl. Acad. Sci. U. S. A., 73: 630 (1976).

7. Fratantoni. J. G., Hall, C. W., and Neufeld. E. G.: The defect in Hurler's and Hunter's syndrome: faulty degradation of mucopolysaccharide. Proc. Natl. Acad. Sci. U. S .A., 60: 699 (1968).

8. Fratantoni, J. C., Neufeld, E. F.. Uhlendorf, W. B., and Jacobsen. C. B.: Intrauterine diagnosis of the Hurler and Hunter syndromes. N. Engl. J. Med.. 280: 686 (1969).

9. Gerich. J. E.: Beta-galactosidase deficiency in skin. New Engl. J. Med., 280: 799 (1969).

10. Greenwood, R. S., Hillman, R. E., Alcala, H., and Sly, W. S.: Sanfilippo syndrome in the fetus. Clin. Genet., 13: 241 (1978).

11. Harper, P. S., Laurence, K. M., Parkes, A.. Wustemann, F. S.. Kresse, H., von Figura, K., Ferguson-Smith, M. A., Duncan, D. M., Logan. R. W., Hall, F., and Whiteman. P.: Sanfilippo A disease in the fetus. J. Med. Genet., $11: 123$ (1974).

12. Haust, M. D.: The genetic mucopolysaccharidoses (GMS). Int. Rev. Exp. Pathol., 12: 251 (1973).

13. Herschkowitz, N., McKhan, G. M., Saxena, A., and Shooter, E. M.: Characterization of sulfatide-containing lipoproteins in rat brain. J. Neurochem.. 15: 1181 (1968).

14. Kint. J. A.: Antagonistic action of chondroitinsulfate and cetylpyridinium chloride on human liver-galactosidase. FEBS Lett.. 36 : 53 (1973).

15. Kint. J. A.. Dacremont. G., Carton, D.. Orye. E., and Hooft. C.: Mucopolysaccharidosis: secondary induced abnormal distribution of lysosomal enzymes. Science (Wash. D. C.), 181: 352 (1973).

16. Liebaers, J., DiNatale, P., and Neufeld. E. F.: Iduronate sulfatase in amniotic fluid: an acid in the prenatal diagnosis of the Hunter syndrome. J. Pediatr.. 9(): 423 (1977).

17. Liebaers, J., and Neufeld. E. F.: Iduronate sulfatase activity in serum. Iymphocytes and fibroblasts-simplified diagnosis of the Hunter syndrome. Pediatr. Res., 10: 733 (1976).

18. McBrinn, M., Okada. S.. Woollacott, M.. Patel. V.. Ho, M. W.. Tappel, A. L.. and O'Brien, J. S.: Beta-galactosidase deficiency in the Hurler Syndrome. N. Eng!. J. Med., 281: 338 (1969).

19. Meier, C., Wiesmann, U., Herschkowitz. N.. and Bischoff, A.: Morphological observations in the nervous system of prenatal Mucopolysaccharidosis II (M. Hunter). Acta Neuropathol., 48: 139 (1979).

20. Rushton, A. R., and Dawson, G.: The effect of glycosaminoglycans on the in vitro activity of human skin fibroblast glycosphingolipid galactosidase and neuramindases. Clin. Chim. Acta, 80:133 (1977).

21. Spranger. J.: The systemic mucopolysaccharidoses. Ergeb. Inn. Med. Kinderheilk.. 32: 165 (1972).

22. Suzuki, K.: Neurochemical aspects of mucopolysaccharidoses. In: A. Lajtha: Handbook of Neurochemistry. Vol. 7. pp. 17-32 (Plenum Press, New York. 1972).

23. Van Hoof, F., and Hers, H. G.: The abnormalities of lysosomal enzymes in mucopolysaccharidoses. Eur. J. Biochem., 7: 34 (1968).

24. Wiesmann. U. N., Rossi, E., and Herschkowitz, N.: Correction of the defective sulfatide degradation in cultured fibroblasts from patients with metachromatic leukodystrophy. Acta Paediatr. Scand., 61: 296 (1972).

25. Wiesmann, U. N., and Rampini, S.: Mild form of Hunter syndrome, identity of the biochemical defect with the severe type. Helv. Paediatr. Acta. 29: 73 (1974).

26. Wiesmann. U. N., Meier. C., Spycher. M. A., Schmid. W., Bischoff, A.. Gauthier, E., and Herschkowitz, N.: Prenatal metachromatic leukodystrophy. Helv. Paediatr. Acta, 30: 31 (1975).

27. Wiesmann, U. N., Hofmann, K., Burkart, T., and Herschkowitz. N.: Dissociated cultures of newborn mouse brain. I. Metabolism of sulfatid lipids and mucopolysaccharides. Neurobiology (Copenh.). 5: 305 (1975).

28. Wolfe. H. J., Blennerhasset, J. B., Joung, G. F., and Cohen, R. B.: Hurler's syndrome: A histochemical study. New techniques for localisation of very water-soluble mucopolysaccharides. Am. J. Pathol., 45: 1007 (1964).

29. Requests for reprints should be addressed to: Dr. Ulrich N. Wiesmann, Department of Pediatrics. University of Bern. Freiburgstrasse 15. 3010 Bern $(\mathrm{CH})$ Switzerland.

30. Received for publication August 27, 1979.

31. Accepted for publication November 29, 1979. 